\title{
Bartter syndrome and cholelithiasis in an infant: is this a mere coincidence?
}

\author{
Pierre Robitaille $\cdot$ Karine Tousignant • Josée Dubois
}

Received: 18 July 2006 / Accepted: 19 December 2006 / Published online: 16 February 2007

(C) Springer-Verlag 2007

Keywords Bartter syndrome - Cholelithiasis .

Metabolic alkalosis

The case of an infant with both Bartter syndrome and cholelithiasis is presented. We felt that this association of two rare diseases might not be coincidental, thus prompting us to publish this report.

Typically, patients affected with Bartter exhibit marked urinary excretion of electrolytes associated with polyuria and, consequently, are prone to develop dehydration [5]. On the other hand, cholelithiasis is a rarely reported condition in infants [4], and several predisposing factors for this condition have been identified such as prematurity, prolonged fasting, parenteral nutrition, use of furosemide, sepsis and dehydration to name a few [3].

This male Caucasian infant was born after 38 weeks of gestation. Presence of severe polyhydramnios had first been noted at 32 weeks of pregnancy. Physical examination of the infant at birth was entirely normal. His serum electrolytes and creatinine were normal during the first two days. Renal ultrasound examination was also unremarkable. On day four it was observed that he had become polyuric and the typical serum electrolyte profile of Bartter had

P. Robitaille $(\bowtie) \cdot K$. Tousignant

Department of Pediatrics, Nephrology Division,

Hôpital Ste-Justine,

3175 Côte Sainte-Catherine,

Montréal, Québec H3T 1C5, Canada

e-mail: probitaillemd@hotmail.com

J. Dubois

Department of Radiology, Hôpital Ste-Justine,

3175 Côte Sainte-Catherine,

Montréal, Québec H3T 1C5, Canada developed. (Serum sodium $135 \mathrm{mmol} / \mathrm{L}$, potassium $2.8 \mathrm{mmol} / \mathrm{L}$, bicarbonate $28.5 \mathrm{mmol} / \mathrm{L}$ and chloride $93 \mathrm{mmol} / \mathrm{L}$ ). Serum creatinine was normal at $32 \mu \mathrm{mol} / \mathrm{L}$, as well as serum magnesium at $0.83 \mathrm{mmol} / \mathrm{L}$ whereas serum calcium was slightly elevated at $2.82 \mathrm{mmol} / \mathrm{L}$.

Urinary osmolality remained low at approximately 130 $140 \mathrm{mOsm} / \mathrm{Kg} \mathrm{H}_{2} \mathrm{O}$ and urinary electrolyte concentrations done on several samples averaged $30 \mathrm{~mm} / \mathrm{L}$ for sodium, $20 \mathrm{~mm} / \mathrm{L}$ for potassium and $40 \mathrm{~mm} / \mathrm{L}$ for chloride. At the same time, plasma renin activity was extremely elevated at $123 \mathrm{ng} / \mathrm{ml}$ per hour (normal 7.1 to 23.8) and plasma aldosterone $954 \mathrm{ng} / \mathrm{dl}$ (normal 30 to 201).

At six months he was admitted for fever, vomiting and passage of discoloured stools. Presence of a gallbladder stone was clearly visible on ultrasound examination (Fig. 1). Fortunately, the child was able to evacuate his gallstone spontaneously. Presence of risk factors for cholelithiasis such as hemolytic disease and hyperlipidemia were not present. In addition, it is noteworthy that the infant had not been administered third generation cephalosporins and he was not fed by hyperalimention nor in a prolonged fasting state.

On follow-up, he proved to be very difficult to manage, requiring enormous electrolyte supplementation in addition to indomethacin and aldactone administration. An adequate state of hydration was obtained through tube feeding by a gastro-jejunostomy. Upon transfer to another medical center in a different city at age 22 months, he was extremely growth retarded at $78 \mathrm{~cm}$ (below the third percentile).

Bartter syndrome and cholelithiasis in infants are both very rare diseases. An association between these two conditions was sought by retrospectively examining abdominal ultrasounds available in six of our patients with Bartter syndrome but no gallstones were found. The association of these two conditions has never been published before. However, we 


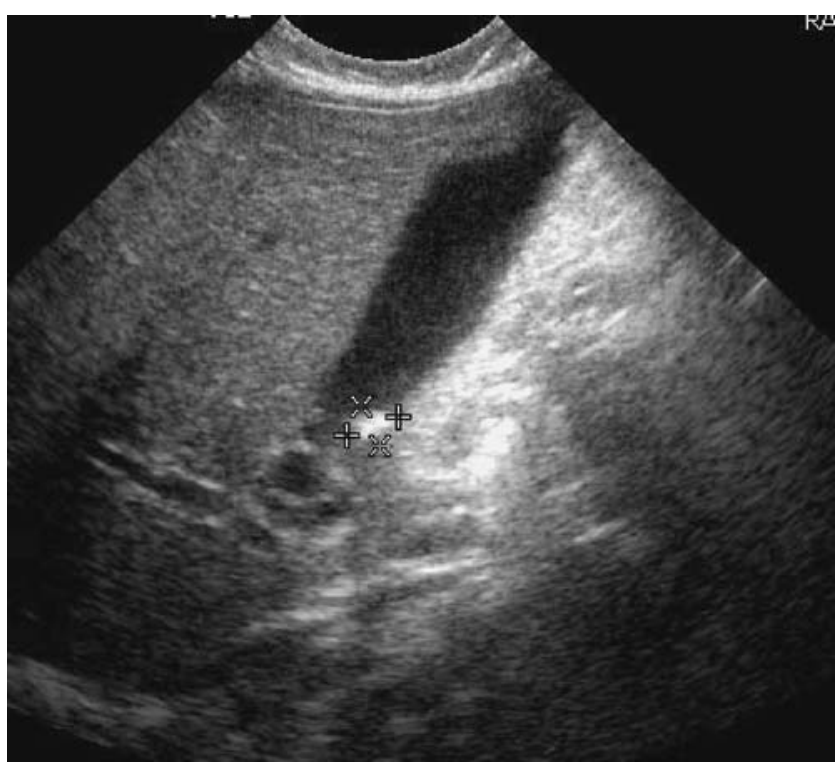

Fig. 1 Ultrasound examination showing presence of a $4 \mathrm{~mm}$ cholelithiasis in the gallbladder neck

asked families of patients with Bartter syndrome if they were aware of the simultaneous occurrence of these two diseases on a web site where patients affected with Bartter can exchange information (http://www.health.groups.yahoo.com/ group/barttersyndrome/message). Surprisingly, several patients with Bartter replied having had cholelithiasis at a young age. Most striking was the case of a female baby born at term with the neonatal variant of Bartter syndrome, where the diagnosis of cholelithiasis was made at three months of age. This suggested that the association is most probably more frequent than it would be expected if there were no connections between the two conditions.
In fact, infants with Bartter typically present with metabolic alkalosis, dehydration and urinary electrolyte losses. It is well established that serum and bile bicarbonate levels are in equilibrium and that alkalinization of bile favours precipitation of calcium carbonate, a key constituent of gallstones [2]. Conversely, systemic acidification induced by acetazolamide has the potential to prevent cholelithiasis formation [6]. Furthermore, dehydration which increases bile viscosity and electrolyte urinary losses such as occurs in pseudohypo-aldosteronism [1] may also promote gallstone formation. Thus factors predisposing to gallstone formation are present in patients with Bartter syndrome and routine ultrasonic screening for gallstones should be performed in these patients who often present bouts of vomiting without obvious explanations.

\section{References}

1. Akkurt I, Kuhnle U, Ringenberg C (1997) Pseudohypo-aldosteronism and cholelithiasis: coincidence or pathogenic correlation? Eur J Pediatr 156:363-366

2. Corbic M, Munoz C, Dumont M, de Couet G, Erlinger S (1985) Effect of systemic $\mathrm{pH}, \mathrm{pCo}^{2}$ and bicarbonate concentration on biliary bicarbonate secretion in the rat. Hepatology 5:594-5990

3. da Cunha AJLA, Barros CRN (2000) Asymptomatic cholelithiasis in a young infant. J Pediatr (Rio J) 76(2):157-161

4. Morad Y, Ziv N, Merob P (1995) Incidental diagnosis of asymptomatic neonatal cholelithiasis: case report and literature review. J Perinatology 15:314-317

5. Proesmans W (1997) Bartter syndrome and its neonatal variant. Eur J Pediatr 156:669-679

6. Wilson B, Valantinas J, Hedin L, Friman S, Svanvik J (2002) Acetazolamide inhibits stimulated feline liver and gallbladder bicarbonate secretion. Acta Physiol Scand 174:117-123 